\title{
Computational Studies and Molecular Dynamic Simulation to Design Lead Compounds for Hepatitis B Virus
}

\author{
Alfan Danny Arbianto ${ }^{1,}$, Firdayani ${ }^{1}$, Susi Kusumaningrum', Raodatul Jannah', ${ }^{1}$ Puspa Dewi N Lotulung ${ }^{2}$, Muhammad Hanafi ${ }^{2}$ \\ 'Badan Pengkajiandan Penerapan Teknologi, JL. MH. Thamrin 8, Jakarta 10340, INDONESIA. \\ ${ }^{2}$ Puslit Kimia LIPI, Kawasan Puspiptek, Serpong, INDONESIA.
}

\begin{abstract}
Objective/Background: A novel approach to develop anti-Hepatitis B Virus (HBV) by computational studies is proposed. Methodology: It used active compounds as the standard ligand. There are six parameters such as docking score, molecular weight, log P, Polarizability, Polar Surface (2D) and Molecular Surface (3D) that analyzed by software. Result and Discussion: The result of virtual screening can be used as a reference to calculate $I C_{50}$ prediction of quinine and Gallic acid derivative compounds. Optimization of compounds structure geometry was using software Marvin Sketch 6.0.1. Meanwhile, virtual docking process to HBV capsid Y132A mutant (PDB ID: 5EOI) was using Autodock4, Auto dock Vina, and Plant. Result: The lowest $\mathrm{IC}_{50}$ prediction is gallic acid $(64.1 \mu \mathrm{M})$ that had hydrogen and polar interaction for $20 \mathrm{~ns}$. Conclusion: These computational studies not only shed light on understanding the $\mathrm{IC}_{50}$ prediction of the replication of the viral core
\end{abstract}

protein inhibition, but also the stability of each interaction that inhibits of the viral core protein replication.

Key words: Amber, Docking, Galic Acid, Hepatitis B, Molecular Dynamic.

\section{Correspondence}

Alfan Danny Arbianto, Badan Pengkajiandan Penerapan Teknologi, JL. MH. Thamrin 8, Jakarta 10340, INDONESIA.

Phone: +6281219971329

Email: alfan.danny@bppt.go.id, icapps2017.farmasiui@gmail.com

DOI: 10.5530/jyp.2018.2s.31

\section{INTRODUCTION}

Hepatitis B virus (HBV) is a small, enveloped, partially double-stranded DNA virus that belongs to the Hepadnaviridae family. HBV is a disease of global concern that caused 1.34 million deaths in 2015, a number comparable to death caused by tuberculosis and higher than those caused by HBV (WHO Global Hepatitis Report, 2017). The number of deaths due to viral hepatitis is increasing over time. Currently, the available antiviral drugs include interferon-alpha (IFN- $\alpha$ ) and nucleotide analogue inhibitors of HBV polymerase, among which lamivudine (3TC), telbivudine (LdT), entecavir (ETV), adefovir (ADV) and tenofovir (TDV) have been approved by the FDA (Figure 1). ${ }^{1} \mathrm{HBV}$ DNA polymerase (HDP) is interested object for treatment of HBV infections in the last few years. There are seven agents are approved for the treatment of chronic HBV. There are two biological products which have shown very good anti-HBV activity such as Interferon alfa-2b (IFN) and long-acting pegylated interferon (peginterferon) alfa-2a (PEG-IFN). However, there are some troubles for that product such as practicality, high cost, effectiveness for the treatment of chronic HBV. There are some publication that studied lead compound for inhibiting the replication of the viral core protein such as a QSAR study on bis (L-amino acid) ester prodrugs of 9-[2-(phosphonomethoxy)ethyl]adenine of anti-HBV agent. ${ }^{1}$ Cannabinoid that found in cannabisplant was effective for HBV- virus treatment. ${ }^{2}$ Virtual screening of Cocculus hirsutus compounds has been studied for anti-HBV by Samuel Thavamani et al. ${ }^{3}$ that used GLID software. ${ }^{4-6}$ Cluster Analysis and QSAR Study of Some Anti-hepatitis B Virus Agents Comprising 4-Aryl-6-chloro-quinolin-2-ones and 5-Aryl-7-chloro-1, 4-benzodiazepines. ${ }^{7}$ Sheng Liu et al. created the docking and synthesis design of phenylpropanoid derivatives for anti - HBV. ${ }^{8}$ Recently, a computational study is the best choice to reduce a cost and time for searching a lead compound. In this article, we report a computational study to predict the $\mathrm{IC}_{50}$ value and molecular dynamic simulation that can be verified the stability of the best compound for a lead compound to HBV.

\section{MATERIALS AND METHODS}

For the present study, the crystal structure of HBV capsid (PDB code 5E0I) were downloaded from the protein data bank (http://www.rcsb. org). 9 A set of standard ligands (Table 1) that inhibit the replication of the viral core protein were taken from the literature.10 The ligands docked onto the active site of HBV core protein using Autodock 4.2,11 Autodock vina12 and Plats program.13 The best ligand result that be continued to molecular dynamic simulation by Amber 14.14

\section{Selection of Standard Compounds}

The compounds were selected from the literature. ${ }^{10}$ The docking set consist derivates of bis (L-amino acid) ester prodrugs of 9-[2-(phosphonomethoxy)ethyl] adenine (PMEA), Lamivudine and Adefovir dipivoxil with $\mathrm{IC}_{50}$ value. To validate the simulation model, that compounds ware used as a test set (see Table 1). The $\mathrm{IC}_{50}$ values in units of $\mathrm{mM}$ were transformed in $\mathrm{pIC}_{50}\left(\operatorname{logIC_{50}}\right)$ to give numerically more significant data.

\section{Docking Studies}

The 2D structures of ligand (standard and samples) were drawn by MarvinSketch 6.01 (Bennet, Clausen et al. 2009) and calculated the lowest energy. The best structure of HBV capsid (PDB code 5E0I).9 was obtained from the Protein Data Bank (http://www.rcsb.org). It has $1.95 \mathrm{~A}$ of resolution. To explore the specific contribution of docking score, molecular weight, log P, Polarizability, Polar Surface (2D) and Molecular Surface (3D) used Autodock 4.2, Autodock Vina, Plant and Marvin Sketch. Autodock 4.2, Autodock Vina and Plant were used 


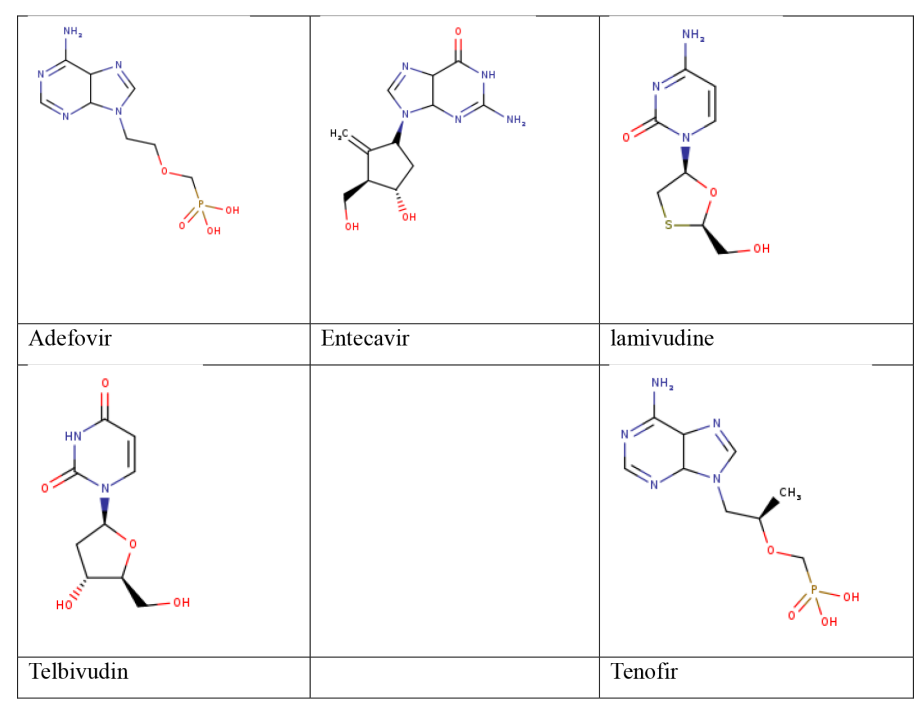

Figure 1: Active compound of HBV that have been approved by the FDA.

conformation calculating of each molecule. Physical properties of each molecule were optimized by Marvin Sketch.

\section{Statistic analysis}

In the present study, five parameters (such as docking score, molecular weight, log P, Polarizability, Polar Surface (2D) and Molecular Surface (3D) of each compound simulation were evaluated using statistic program for getting the equation.

\section{Molecular Dynamic Simulation}

The simulation was carried out using the Amber 14 Molecular Dynamics package. ${ }^{9}$ The system, prepared as solvated complex by carrying out a
Table 1: Structure and experimental anti-HBV activities of standard compounds.

\begin{tabular}{ccccc} 
& & & \\
\hline \\
\end{tabular}

Table 2: The docking score and physic properties of the standard.

\begin{tabular}{|c|c|c|c|c|c|c|c|c|}
\hline \multirow{2}{*}{$\begin{array}{l}\text { Standard } \\
\text { ID }\end{array}$} & \multicolumn{3}{|c|}{ Docking Score } & \multirow[b]{2}{*}{$\mathrm{Mr}$} & \multirow[b]{2}{*}{$\log P$} & \multirow{2}{*}{$\begin{array}{l}\text { Polari } \\
\text { zability }\end{array}$} & \multirow{2}{*}{$\begin{array}{l}\text { Polar } \\
\text { Surface } \\
\text { (2D) }\end{array}$} & \multirow{2}{*}{$\begin{array}{c}\text { Molecular } \\
\text { Surface } \\
\text { (3D) }\end{array}$} \\
\hline & $\begin{array}{c}\text { Autodock } \\
4.2\end{array}$ & $\begin{array}{c}\text { Autodock } \\
\text { vina }\end{array}$ & Plant & & & & & \\
\hline 1 & -0.99 & -4.60 & -102.81 & 503.45 & -1.77 & 47.41 & 220.64 & 728.46 \\
\hline 2 & -0.71 & -5.20 & -113.75 & 559.56 & -0.02 & 54.71 & 222.26 & 853.16 \\
\hline 3 & 0.69 & -5.20 & -116.54 & 587.62 & 0.82 & 58.36 & 222.26 & 920.41 \\
\hline 4 & -1.33 & -5.60 & -123.58 & 627.60 & 0.98 & 62.75 & 219.02 & 827.85 \\
\hline 5 & 0.16 & -4.80 & -93.69 & 507.52 & -1.91 & 48.48 & 203.80 & 689.74 \\
\hline 6 & -1.48 & -4.90 & -100.98 & 535.57 & -0.86 & 52.13 & 203.80 & 747.17 \\
\hline 7 & -0.18 & -5.00 & -112.56 & 591.68 & 0.89 & 59.45 & 203.80 & 865.76 \\
\hline 8 & 0.37 & -5.20 & -116.94 & 619.74 & 1.73 & 63.11 & 203.80 & 933.10 \\
\hline 9 & -1.99 & -5.90 & -123.34 & 659.72 & 1.89 & 67.52 & 202.18 & 892.20 \\
\hline 10 & -2.25 & -5.10 & -101.16 & 499.51 & 0.44 & 49.57 & 203.80 & 755.31 \\
\hline 11 & -0.84 & -5.70 & -106.25 & 527.56 & 1.28 & 53.23 & 203.80 & 817.84 \\
\hline 12 & -2.65 & -6.30 & -114.00 & 567.54 & 1.44 & 57.63 & 202.18 & 780.38 \\
\hline $\begin{array}{l}\text { Adefovir } \\
\text { dipivoxil }\end{array}$ & -2.43 & -5.90 & -100.24 & 501.48 & 3.06 & 48.00 & 166.98 & 764.47 \\
\hline Lamividine & -4.05 & -5.00 & -60.07 & 229.25 & -1.10 & 21.35 & 88.15 & 273.28 \\
\hline
\end{tabular}


Table 3: Data of PIC $_{50}$ prediction for standard compound.

\begin{tabular}{cccc}
\hline PIC $_{50}$ & Autodock 4.2 & Autodock vina & Plants \\
\hline 3.3 & 3.0 & 2.9 & 3.0 \\
3.4 & 3.6 & 3.5 & 3.6 \\
3.8 & 3.7 & 3.8 & 3.9 \\
3.4 & 3.5 & 3.7 & 3.7 \\
2.4 & 2.7 & 2.9 & 2.8 \\
3.4 & 3.3 & 3.2 & 3.1 \\
4.5 & 3.7 & 3.8 & 3.7 \\
3.5 & 4.0 & 4.0 & 4.0 \\
4.0 & 4.1 & 4.0 & 4.0 \\
3.5 & 3.8 & 3.7 & 3.6 \\
3.9 & 3.9 & 4.0 & 3.9 \\
4.2 & 4.0 & 3.9 & 3.9 \\
2.7 & 2.8 & 2.8 & 2.7 \\
2.4 & 2.3 & 2.4 & 2.4 \\
Multiple r & 0.9 & 0.9 & 0.9 \\
\hline
\end{tabular}

Table 4: Value of $I C_{50}$ prediction calculation of compounds.

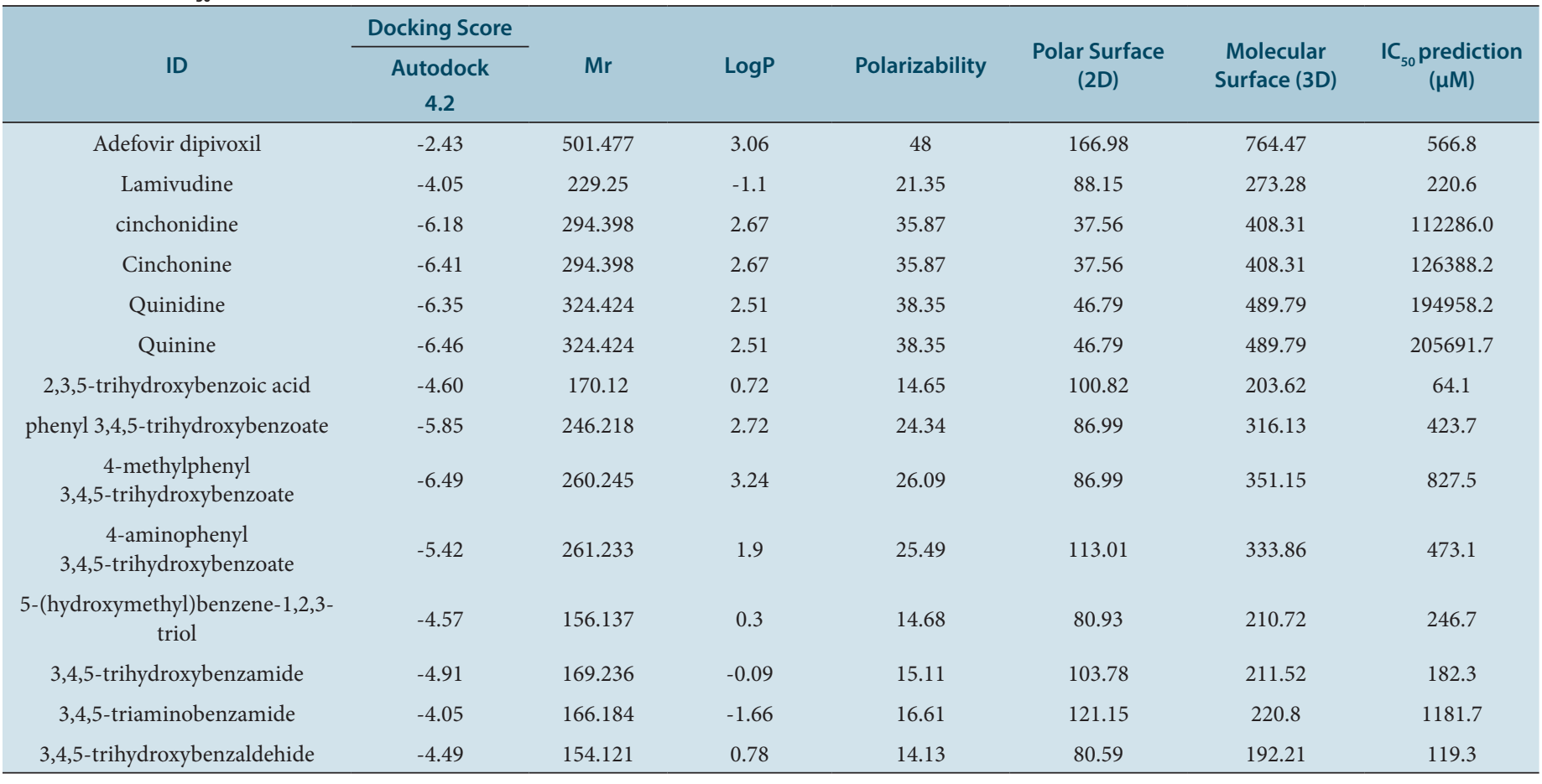

short minimization, 50 ps of heating, 50 ps of density equilibration with weak restraints on the complex followed by 500 ps of constant pressure equilibration at $300 \mathrm{~K}$. The production phase of the simulation was run using the same conditions as the final phase of equilibration for $20 \mathrm{~ns}$ (production recording the coordinates every $10 \mathrm{ps}$ ). The simulation results were analyzed using the ptraj program in the Amber 14 package and VMD.

\section{RESULT}

Docking studies have been done on the compound structure of standard which is already successfully synthesized and known its activity as antiHBV (see Table 1).

\section{DISCUSSION}

\section{Docking Studies}

Docking studies have been done on the compound structure of standard which is already successfully synthesized and known its activity as antiHBV that will be a standard ligand for docking simulation on 5E0I using Autodock 4.2, Autodock vina and Plant. We will obtain docking score information (the lowest energy of ligand pose) and physic properties (Table 2). Statistical analysis has been done using a multivariate method and is obtained an equation that will be used to predict $\mathrm{IC}_{50}$ of the compound in Curcuma (Eq 1, 2 and 3). 
pIC50 prediction $=1.061-0.220$ Docking Score -0.038 Molecular Weight $-0.182 \log \mathrm{P}+0.329$ Polarizability +0.003 Polar Surface (2D) + 0.006 Molecular Surface (Eq. 1)

pIC50 prediction $=2.693+0.054$ Docking Score -0.038 Molecular weight $+0.059 \log \mathrm{P}+0.346$ Polarizability +0.013 Polar Surface (2D) + 0.001 Molecular Surface (3D) (Eq.2)

pIC50 prediction $=1.715-0.026$ Docking Score -0.038 Molecular Weight $-0.039 \log \mathrm{P}+0.317$ Polarizability + 0.007 Polar Surface (2D) + 0.002 Molecular Surface (3D) (Eq.3)

Six parameters which are obtained from docking score, molecular weight, $\log$ P, Polarizability, Polar Surface (2D) and Molecular Surface (3D) are proven determining $\mathrm{IC}_{50}$ calculation (multiple $\mathrm{r}$ ). The multiple results were shown in Table $3( \pm 0.9)$ that given the correlation of six parameters. The $\mathrm{IC}_{50}$ prediction that calculated by three equations shown at Table 4.

The hydrogen bond and van der Waals interaction that given the lowest $\mathrm{IC}_{50}$ of 2, 3, 5-trihydroxybenzoic acid. 2, 3, 5-trihydroxybenzoic acid has six hydrogen bond interaction and five teen van der Waals interaction.

\section{Molecular Dynamic Simulation}

The relative stability of the whole model can be measured as the root mean square deviation (RMSD) of backbone atoms from the initial structure as a function of time. The model built with the ptraj program in the Amber 14 package was taken as the initial structure for comparison. The RMSD in Figure 2 was calculated for each MD snapshot (one every $10 \mathrm{ps)}$ ) after the coordinates of the model were superimposed on the coordinates of the initial structure. The backbone RMSD values of the two systems tend to be convergent after 2 ns of simulation, with fluctuations of $4.5 \AA$ and $4 \AA$ approximately for the structures of the viral core protein. It means the system of molecular dynamic was stable during the simulation interaction.

The structures from before and after MD simulation are shown in Figure 3. Docking into the protein structure obtained after $20 \mathrm{~ns}$ of MD simulation produced smaller binding energy interaction poses than before MD simulation. The docking score that got after MD simulation shown at Table 5 .

The Total energy of 2, 3, 5-trihydroxybenzoic acid after MD simulation was lower than before MD simulation, it means the structure of 2,3,5-trihydroxybenzoic acid was stable during simulation that can inhibit viral core protein replication.

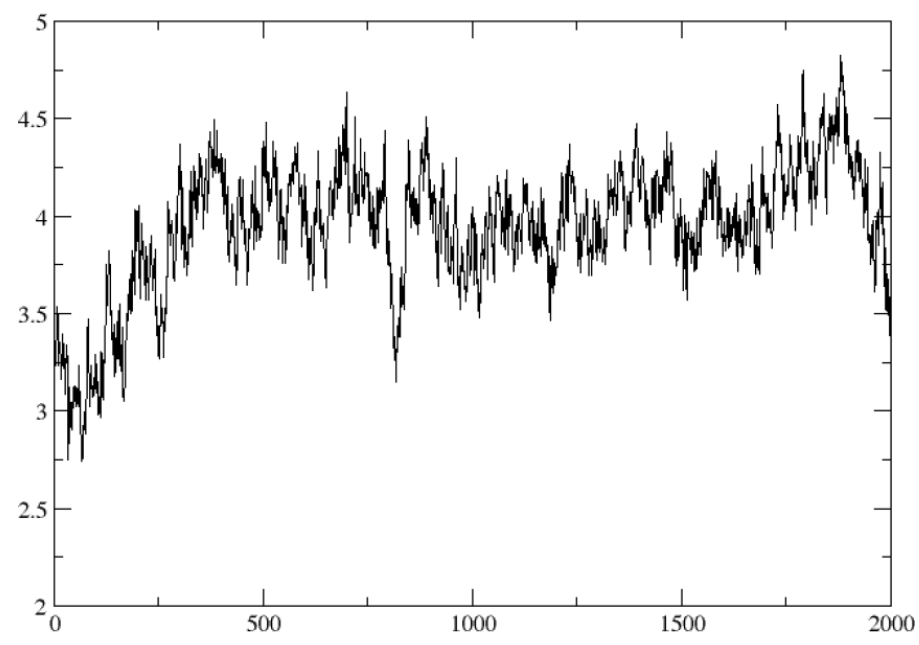

Figure 2: Backbone RMSD for $20 \mathrm{~ns}$.
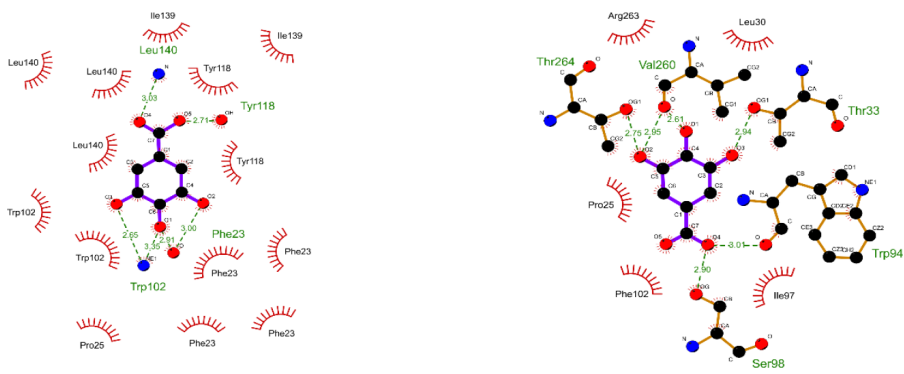

Figure 3: The interaction of 2, 3, 5-trihydroxybenzoic acid (a). before MD simulation (b). after MD simulation.

Table 5: The docking score of Value of 2, 3, 5-trihydroxybenzoic acid before and after MD simulation.

\begin{tabular}{ccc}
\hline Compound & $\begin{array}{c}\Delta \mathrm{G}(\mathrm{kcal} / \mathrm{mol}) \text { before } \mathrm{MD} \\
\text { simulation }\end{array}$ & $\begin{array}{c}\Delta \mathrm{G}(\mathrm{kcal} / \mathrm{mol}) \text { after } \\
\mathrm{MD} \text { simulation }\end{array}$ \\
\hline $\begin{array}{c}2,3,5 \text {-trihydroxybenzoic } \\
\text { acid }\end{array}$ & -4.60 & -5.50 \\
\hline
\end{tabular}

\section{CONCLUSION}

In conclusion, these computational studies not only shed light on understanding the $\mathrm{IC}_{50}$ prediction of the replication of the viral core protein inhibition, but also the stability of each interaction that inhibits of the viral core protein replication.

\section{ACKNOWLEDGEMENT}

The authors would like to acknowledge funding for this project from the government program (insinas).

\section{ABBREVIATIONS}

HBV (Hepatitis B Virus), RMSD (root mean square deviation), MD (molecular dynamic)

\section{CONFLICT OF INTEREST}

The authors whose names are listed certify that they have NO affiliations with or involvement in any organization or entity with any financial interest (such as honoraria; educational grants; participation in speakers' bureaus; membership, employment, consultancies, stock ownership, or other equity interest; and expert testimony or patent-licensing arrangements), or non-financial interest (such as personal or professional relationships, affiliations, knowledge or beliefs) in the subject matter or materials discussed in this manuscript.

\section{SUMMARY}

A novel approach to develop anti-Hepatitis B Virus (HBV) by computational studies is proposed. It used $2 \mathrm{D}$ and $3 \mathrm{D}$ software interaction. The result of virtual screening can be used as a reference to calculate $\mathrm{IC}_{50}$ prediction of quinine and Gallic acid derivative compounds. The lowest $\mathrm{IC}_{50}$ prediction is gallic acid $(64.1 \mu \mathrm{M})$ that had hydrogen and polar interaction for $20 \mathrm{~ns}$. These computational studies not only shed light on understanding the $\mathrm{IC}_{50}$ prediction of the replication of the viral core

\section{REFERENCES}

1. Fu X, Jiang S, Li C, Xin J, Yang Y, Ji R. Design and synthesis of novel bis(l-amino acid) ester prodrugs of 9-[2-(phosphonomethoxy)ethyl]adenine (PMEA) with improved anti-HBV activity. Bioorg Med Chem Lett. 2007;17(2):465-70.

2. Lowe HIC, Toyang NJ, McLaughlin W. Potential of cannabidiol for the treatment of viral hepatitis. Pharmacognosy Res. 2017;9(1):116-8. 
3. Thavamani BS, Mathew M, Dhanabal SP. Cocculus hirsutus: Molecular docking to identify suitable targets for hepatocellular carcinoma by in silico technique. Pharmacogn Mag. 2016;12(3):S350-S2.

4. Shelley JC, Cholleti A, Frye LL, Greenwood JR, Timlin MR, Uchimaya M. Epik: A software program for pKa prediction and protonation state generation for druglike molecules. J Comput Aided Mol Des. 2007;21(12):681-91.

5. Halgren TA, Murphy RB, Friesner RA, Beard HS, Frye LL, PollardWT, et al. Glide: A new approach for rapid, accurate docking and scoring. 2. Enrichment factors in database screening. J Med Chem. 2004;47(7):1750-9.

6. Friesner RA, Murphy RB, Repasky MP, Frye LL, Greenwood JR, Halgren TA, et al. Extra precision glide: Docking and scoring incorporating a model of hydrophobic enclosure for protein-ligand complexes. J Med Chem. 2006;49(21):6177-96.

7. Li Z, Chen K, Xie H, Wang Y, Dong F. Cluster analysis and QSAR study of some anti-hepatitis B virus agents comprising 4-Aryl-6-chloro-quinolin-2-ones and 5-Aryl-7-chloro-1,4-benzodiazepines. Chin J Chem. 2009;27(12):2352-8.

8. Liu S, LiY, WeiW, Wang K, Wang L, Wang J. Design, synthesis, molecular docking studies and anti-HBV activity of phenylpropanoid derivatives. Chem Biol Interact. $2016 ; 251: 1-9$
9. Klumpp K, Lam AM, Lukacs C, Vogel R, Ren S, Espiritu C, et al. High-resolution crystal structure of a hepatitis $B$ virus replication inhibitor bound to the viral core protein. Proc Natl Acad Sci USA. 2015;112(49):15196-201.

10. Arora PK, Patil VM, Gupta SP. A QSAR study on some series of antihepatitis B virus (HBV) agents. Bioinformation. 2010;4(9):417-20.

11. Morris GM, Huey R, Lindstrom W, Sanner MF, Belew RK, Goodsell DS, et al. AutoDock4 and AutoDockTools4: Automated Docking with Selective Receptor Flexibility. J Comput Chem. 2009;30(16):2785-91.

12. Trott O, Olson AJ. AutoDock Vina: Improving the speed and accuracy of docking with a new scoring function, efficient optimization, and multithreading. J Comput Chem. 2010;31(2):455-61.

13. Korb O, Stützle T, Exner TE. Empirical Scoring Functions for Advanced ProteinLigand Docking with PLANTS. J Chem Inf Model. 2009;49(1):84-96.

14. Case DA, Babin V, Berryman JT, Betz RM, Cai Q, Cerutti DS, et al. AMBER 14. 2014. University of California, San Fransisco. 2014;14:29-31.

Article History: Submission Date : 20-02-2018 ; Revised Date : 04-03-2018; Acceptance Date : 13-05-2018.

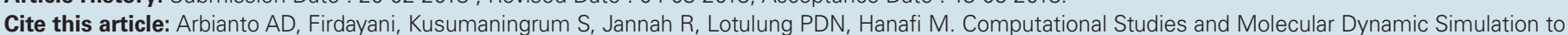
Design Lead Compounds for Hepatitis B Virus. J Young Pharm. 2018;10(2)Suppl:s148-s152. 